\title{
Fever Management in Preschool Children; What Do the Parents Know? What Are They Doing?
}

\author{
Okul Öncesi Çocuklarda Ateş Yönetimi; Ebeveynler Ne Biliyorlar? Ne Yapıyorlar?
}

\author{
Hatice Tuba Akbayram(ID) \\ Department of Family Practice, Gaziantep University Faculty of Medicine, Gaziantep, Turkey
}

Cite this article as: Akbayram HT. Fever management in preschool children; what do the parents know? What are they doing? J Pediatr Inf 2021;15(3):e152-e158.

\begin{abstract}
Objective: Fever, one of the most common symptoms of illness in children, causes anxiety in parents and leads to wrong practices in reducing fever. This study was conducted to evaluate parents' knowledge, attitudes and practices regarding fever management.
\end{abstract}

Material and Methods: Two hundred fifty-three parents with children aged between six months and six years who applied to pediatric outpatient clinics between November 2019 and January 2020 in a university hospital were included. The data were collected by face-to-face interview technique using a questionnaire form consisting of 21 questions.

Results: It was found that when their children had a fever, $56.9 \%$ of the participants were very anxious and feared the most of convulsions $(55.7 \%)$, the fever was mostly evaluated by touching $(59.7 \%)$ and forehead $(41.5 \%)$. It was observed that $22.5 \%$ of the parents did not know the degree of fever, $43.5 \%$ of parents considered temperatures below $38^{\circ} \mathrm{C}$ as fever, and $30.8 \%$ of parents used antipyretic drugs at temperatures below $38^{\circ} \mathrm{C}$. The use of antipyretic drugs for the temperatures below $38^{\circ} \mathrm{C}$ by the university graduate parents was significantly lower than the other parents $(p<0.05)$. First applications in reducing fever; removing clothes (27.3\%) and having a bath (27.3\%) with warm water. It was found that giving antipyretic before going to the doctor was $73.5 \%$, checking fever more frequently than an hour $73.1 \%$ and giving antipyretic drugs by waking up from sleep at night was found as $74.3 \%$. The rate of using different antipyretic drugs alternately was $49 \%$, and the rate of giving antipyretics to prevent fever after the fever subsided was found to be $32.8 \%$.

Conclusion: It was found that most of the parents had insufficient information regarding fever, were extremely anxious, measured fever fre-
Öz

Giriş: Çocuklarda sık görülen hastalık belirtilerinden birisi olan ateş, ebeveynlerde endişeye neden olarak ateş düşürmede yanlış uygulamalara yol açmaktadır. Bu çalışma, ebeveynlerin ateş yönetimi ilgili bilgi, tutum ve uygulamalarını değerlendirmek amacıyla yapılmıştır.

Gereç ve Yöntemler: Kasım 2019-Ocak 2020 tarihleri arasında bir üniversite hastanesinde yapılan çalışmaya, çocuk sağlığı ve hastalıkları polikliniklerine başvuran 6 ay- 6 yaş arasında çocuğu olan 253 ebeveyn dahil edilmiştir. Veriler 21 sorudan oluşan anket formu kullanılarak yüz yüze görüşme tekniğiyle toplanmıştır.

Bulgular: Çocuklarında ateş olduğunda, katılımcıların \%56.9'unun fazla endişeli olduğu ve en fazla (\%55.7) havaleden korktukları, ateşin en fazla (\%59.7) dokunarak ve alından (\%41.5) değerlendirildiği bulundu. Ebeveynlerin \%22.5'inin ateşin derecesini bilmediği, \%43.5'inin $38^{\circ} \mathrm{C}^{\prime}$ nin altındaki sıcaklıkları ateş olarak değerlendirdiği, \%29.3'ünün $38^{\circ} \mathrm{C}^{\prime}$ nin altındaki sıcaklıklarda ateş düşürücü ilaç kullandığı saptandı. Üniversite mezunu ebeveynlerin $38^{\circ} \mathrm{C}^{\prime}$ nin altındaki sıcaklıklar için ateş düşürücü ilaç kullanmaları diğer ebeveynlere göre anlamlı olarak düşüktü $(p<0.05)$. Ateş düşürmede ilk uygulamalar; kıyafetleri çıkarma (\%27.3) ve ılık suyla banyo (\%27.3) yaptırmaktı. Doktora gitmeden önce ateş düşürücü verme \%73.5, ateşi bir saatten daha sık aralıklarla kontrol etme \%73.1 ve gece uykudan uyandırarak ateş düşürücü ilaç verme \%74.3 olarak saptandı. Dönüşümlü farklı ateş düşürücü ilaçları kullanma \%49, ateş düştükten sonra ateşin çıkmaması için ateş düşürücü verme \%32.8 olarak bulundu.

Sonuç: Ebeveynlerin büyük bir kısmının ateş ile ilgili bilgilerinin yetersiz olduğu, fazla endişeli oldukları, ateşi sık aralıklarla kontrol ettikleri, gece uykudan uyandırma, düşük sıcaklık derecelerinde ateş düşürücü kullan-

Correspondence Address/Yazışma Adresi

Hatice Tuba Akbayram

Gaziantep Üniversitesi Tıp Fakültesi,

Aile Hekimliği Anabilim Dalı,

Gaziantep-Türkiye

E-mail: tubaakbayram@gmail.com 
quently, used wrong practices such as waking children up at night, using antipyretics at low temperatures, and giving antipyretics alternately.

Keywords: Fever, knowledge, child, parent, fever management

\section{Introduction}

Fever, which is one of the most commonly seen symptoms in preschool children, generally results from self-limiting viral infections, and most of these diseases improve without any special treatment $(1,2)$. Fever is a physiological response of the body that fastens and eases recovery (3). For a child properly dressed for the ambient temperature, acute fever is defined as body core temperature higher than $38^{\circ} \mathrm{C}$ without any physical activity (4).

There is no evidence for fever itself to worsen the course of the disease or cause long term neurological complications (5). However, fever in a child is a worrisome condition for parents. It has been reported that main reasons for parents to fear fever are brain damage, febrile seizure and death $(6,7)$.

Excessive concern of the parents regarding fever was defined as "fever phobia" in a study conducted by Schmitt for the first time in 1980 (8). It has been shown in later studies that this concern continued, parents' knowledge on fever was insufficient, and parents tried improper practices to bring the fever down (6,7,9-11).

Negative thoughts of the parents regarding fever may increase their concerns and affect fever management strategies (6). Concerns on fever lead to unreasonable admissions to healthcare centers and inappropriate use of antipyretics (3). It is mandatory for healthcare providers to inform parents on not to panic when their children have fever, not to get overly concerned, and to properly manage fever at home. It is important to determine parents' lack of knowledge on how to bring fever down with up-to-date studies and to detect improper practices performed at home in fever management to give information correctly to parents. This study was carried out to evaluate the knowledge, attitude and practices on fever management in parents with preschool children.

\section{Materials and Methods}

This cross-sectional study was performed in Gaziantep University, Medical Faculty, Education and Research Hospital between November 2019 and January 2020. Prior to the study, approval was obtained from the Medical Faculty Ethics Board of Gaziantep University (Decision no:2019/424).

In a recent study conducted in Turkey, the rate of parents' knowledge on the correct definition of fever has been found approximately as 19\% (10). Based on the aforementioned study, sample size for this study (95\% confidence interval and $5 \%$ margin of error) was calculated as 237 . Due to shortcom- ma ve dönüşümlü olarak ateş düşürücü verme gibi yanlış uygulamalar yaptıkları bulunmuştur.

Anahtar Kelimeler: Ateş, bilgi, çocuk, ebeveyn, ateş yönetimi

ings that could be seen in data, the number was increased at a rate of approximately $10 \%$ and planned as 260 .

During the study period, parents with children aged 6 months to 6 years who presented to the pediatric health and diseases polyclinic for any reason were informed on the study. Parents with children who had congenital anomalies, chronic diseases, cancer and were immunosuppressive were excluded from the study. A survey was filled out face-to-face with 260 parents agreeing to participate in the study. Seven parents who did not answer some of the questions on the survey were excluded from the study. A total of 253 parents were included into the study.

The survey form prepared by the researcher screening the literature was made up of 21 questions, including mainly multiple-choice questions. The survey had three parts. The first part included questions regarding demographics of the parents (age, sex, education, monthly income, number of children in the family, history of febrile convulsion in the family). The second part of the survey included questions on how temperature is taken, the definition of fever, on which degrees of temperature antipyretics are given, the reasons to fear fever, and the level of concern. The last part of the study included questions on the practices parents carried out at home to bring fever down, how often fever is checked and how antipyretics are given.

Chi-square test was used to analyze the interrelation of two independent variables for categorical variables. As descriptive statistics, mean and standard deviation were used for numerical variables, and number and percentage were used for categorical variables. SPSS 23.0 was sued for statistical analyses, and $p<0.05$ was considered statistically significant.

\section{Results}

\section{Demographics of the Parents}

Mean age of the parents was $32.85 \pm 6.47$ (youngest 19oldest 54$)$, and $69.2 \%$ were mothers $(n=175)$. Of the participants, $29.6 \%$ were primary school graduates $(n=75)$. Of the parents, 38.7\% stated that their income was under 2,500 TL. Majority of the parents in this study $(80.2 \% n=203)$ had more than 1 child. History of convulsion in the family was $7.5 \%$ ( $n=$ 19). Demographic characteristics of the parents are summarized in Table 1.

\section{Parents' Concern on Fever and Definition of Fever}

Of the parents, $56.9 \%$ stated that they felt very concerned when their children had fever and that they mostly feared fe- 
Table 1. Demographics of the parents

\begin{tabular}{|c|c|c|}
\hline Demographics of the parents & $\mathrm{n}$ & $\%$ \\
\hline $\begin{array}{l}\text { Age } \\
\text { Under } 35 \text { years } \\
35 \text { years and over }\end{array}$ & $\begin{array}{c}154 \\
99\end{array}$ & $\begin{array}{l}60.9 \\
39.1\end{array}$ \\
\hline Age mean $\pm S D$ & $32.85 \pm 6.47$ & \\
\hline $\begin{array}{l}\text { Sex } \\
\text { Male } \\
\text { Female }\end{array}$ & $\begin{array}{c}78 \\
175\end{array}$ & $\begin{array}{l}30.8 \\
69.2 \\
\end{array}$ \\
\hline $\begin{array}{l}\text { Level of education } \\
\text { Primary school } \\
\text { Secondary school } \\
\text { High school } \\
\text { University }\end{array}$ & $\begin{array}{l}75 \\
46 \\
67 \\
65 \\
\end{array}$ & $\begin{array}{l}29.6 \\
18.2 \\
26.5 \\
25.7 \\
\end{array}$ \\
\hline $\begin{array}{l}\text { Level of income } \\
\text { Under } 2500 \mathrm{TL} \\
2500-5000 \mathrm{TL} \\
\text { Over } 5000 \mathrm{TL}\end{array}$ & $\begin{array}{l}98 \\
95 \\
60\end{array}$ & $\begin{array}{l}38.7 \\
37.5 \\
23.7\end{array}$ \\
\hline $\begin{array}{l}\text { Number of children } \\
1 \\
2 \\
3 \text { and over }\end{array}$ & $\begin{array}{c}50 \\
101 \\
102\end{array}$ & $\begin{array}{l}19.8 \\
39.9 \\
40.3\end{array}$ \\
\hline $\begin{array}{l}\text { Family history of febrile convulsion } \\
\text { Yes } \\
\text { No }\end{array}$ & $\begin{array}{c}19 \\
234\end{array}$ & $\begin{array}{c}7.5 \\
92.5\end{array}$ \\
\hline
\end{tabular}

brile convulsion (55.7\%). The level of concern of parents with a history of convulsion in the family was found significantly higher compared to those that did not have the same history $(p=0.012)$. Of the parents, $59.7 \%(n=151)$ replied to the question "how do you understand if your child has fever?" as "by touching". It was found that temperature was mostly evaluated from the forehead $(41.5 \%, n=105)$. Parents with a university degree were found to take temperature using a thermometer more than the other parents. Of the parents, $22.5 \%(n=57)$ indicated that they did not know the answer to the question "Over what degree is considered fever?". Table 2 shows the definition and concerns of the parents regarding fever.

Of the parents, $43.5 \%(n=110)$ stated that they considered temperature under $38^{\circ} \mathrm{C}$ as fever, and $29.3 \%$ indicated that they used antipyretic drugs for temperatures under 38 ${ }^{\circ} \mathrm{C}$. More than half of the university graduate parents $(53.8 \%)$ stated that they considered temperatures under $38^{\circ} \mathrm{C}$ as fever. University graduate parents were found to define temperatures under $38^{\circ} \mathrm{C}$ as fever more than other parents $(p=0.023)$. The usage of antipyretic drugs for temperatures under $38^{\circ} \mathrm{C}$ was found to be significantly lower compared to other parents $(p=0.014)$ (Table 3).

\section{Practices of the Parents on Fever Management}

The first practices that parents carried out when the child had fever were found to be taking the child's clothes off (27.3\%) and bathing the child in warm water (27.3\%). Majori- ty of the parents (73.5\%) stated that they gave their children antipyretic drugs before applying to a physician and checked their children's temperature at less than one-hour intervals (73.1\%).

Of the parents, $22.9 \%$ stated that they had difficulty in choosing the antipyretic drug to use, and $49 \%$ indicated that they used different antipyretic drugs alternately if the fever persisted. It was found that mostly paracetamol-containing drugs were used as antipyretics (49\%). Of the parents, $74 \%$ ( $n=$ 188) emphasized that they woke the child up at night to give antipyretic drug, and $32.8 \%$ were detected to give antipyretic drug to prevent the temperature going up once the fever dropped. Practices of the parents to bring the fever down are summarized in Table 4.

\section{Discussion}

Concerns of the parents and caregivers regarding the serious reasons of fever (like severe bacterial infections) and their illusion regarding the fact that fever is a trigger of brain damage cause fever phobia to continue (12). In a recent study from Saudi Arabia, it has been reported that $99 \%$ of the parents consider untreated fever to lead to convulsion, brain damage and death (13). In other studies, it has been demonstrated that the main reasons for parents to fear fever are convulsion, brain damage and death $(6,9,14)$. Similarly, our study also found that parents mostly feared fever due to convulsion (febrile seizures). 
Table 2. Parents' concern regarding fever and their definitions of fever

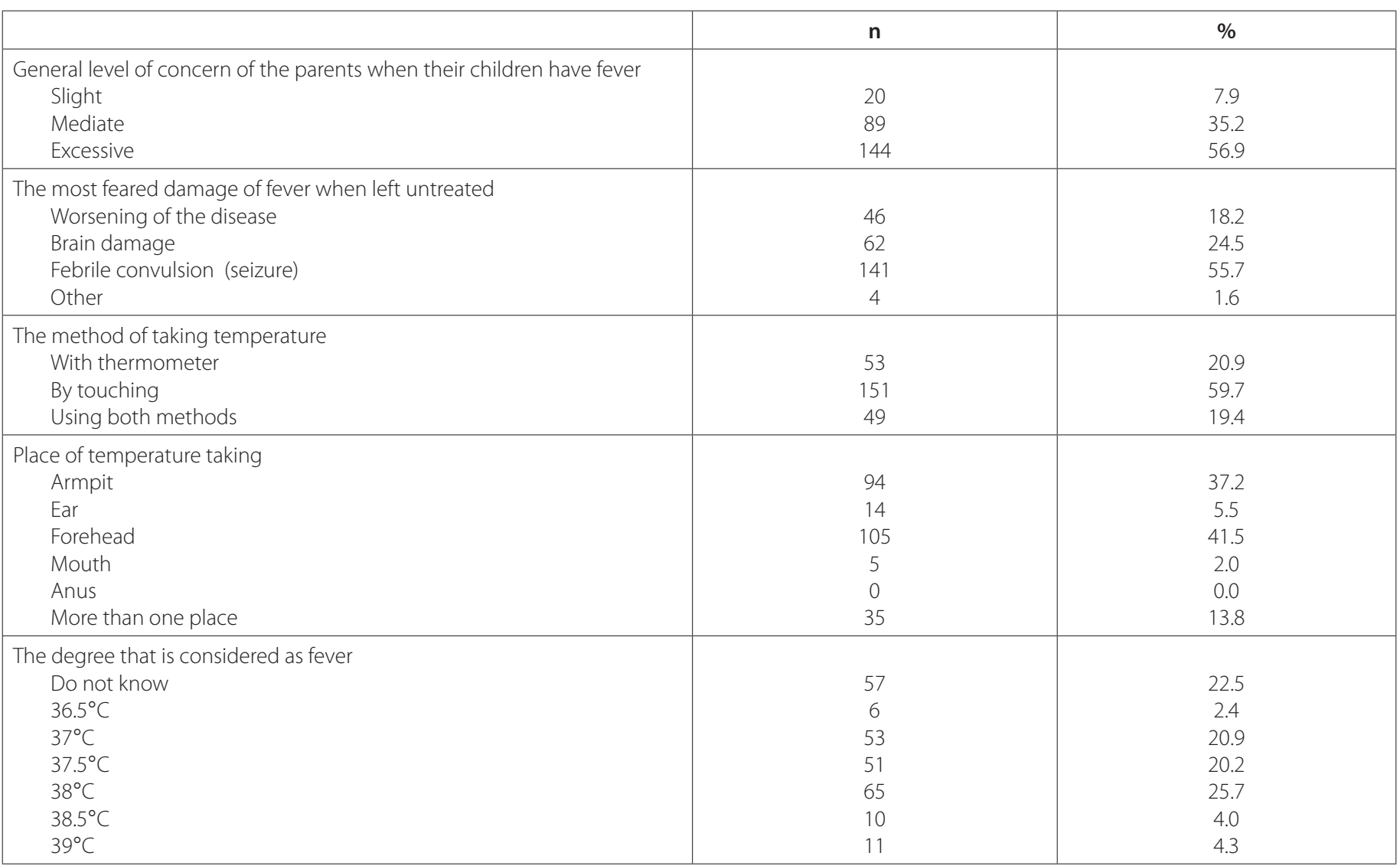

Fever in children is evaluated by touching by most parents (15). In a study conducted in Palestine, it has been detected that $65.4 \%$ of the parents evaluate the temperature of their children only by touching (7). In a study from New York, it has been reported that measuring temperature by touching with hand is used by $57 \%$ of the parents and mostly, the forehead is being preferred (15). Erkek et al. have reported in their study that $56.5 \%$ of the parents evaluated temperature by touching the forehead (16). Similarly, our study found that more than half of the parents (59.7\%) evaluated temperature by touching and mostly by touching the forehead (41.5\%).

The degree of body temperature may change depending on the place the temperature is taken. It also varies among individuals and during the day (17). In the literature, body temperature to be referred to as fever in children has been defined as over $38^{\circ} \mathrm{C}(4,17-19)$. Coretti et al. have reported that half of the caregivers considered temperature under $38^{\circ} \mathrm{C}$ as fever and one fourth of them used antipyretics in temperatures under $37.8^{\circ} \mathrm{C}(9)$. In a study conducted in Ireland, it has been found that two thirds of parents consider temperature under $38^{\circ} \mathrm{C}$ as fever (20). In a study by Polat et al. it has been reported that approximately one third of parents consider temperature under $37.8^{\circ} \mathrm{C}$ as fever (21). Similarly, this study also found that
$22.5 \%$ of the parents did not know what degree is considered as fever and $43.5 \%$ considered temperature under $38^{\circ} \mathrm{C}$ as fever.

It has been reported that level of education is important in the parents' management of fever (22). In a study, it has been detected that delaying the administration of antipyretics until the fever reaches $38.5^{\circ} \mathrm{C}$ was more in parents with high level of education (23). In a study by Hiller et al. positive perception of fever is related to the education level of the parents (24). In a study by Arıca et al., a significant relation has been established between the mothers' education level and correct evaluation of fever (25). In our study, defining temperature under $38^{\circ} \mathrm{C}$ as fever was found to be more frequent in parents that had graduated from university compared to others but their usage of antipyretics was found significantly lower compared to others $(p<0.05)$.

According to the American Pediatric Academy, primary objective of using antipyretic drugs in a child with fever is to increase general comfort (26). In order to bring fever down, parents tend to use antipyretics more frequently than recommended, at improper dosages, and in combination or alternately unnecessarily (9). Combined or alternate usage of two antipyretic drugs may increase the risk of drug toxicity (12). In 
Table 3. Comparison of the parents' education level and the method used in taking temperature

\begin{tabular}{|c|c|c|c|c|}
\hline & & No university degree & University graduates & $\mathbf{p}$ \\
\hline \multicolumn{5}{|c|}{ How do you understand if your child has fever? } \\
\hline \multirow{2}{*}{ Use thermometer } & $\mathrm{n}$ & 37 & 16 & \multirow{6}{*}{0.002} \\
\hline & $\%$ & 19.7 & 24.6 & \\
\hline \multirow{2}{*}{ By touching } & $\mathrm{n}$ & 123 & 28 & \\
\hline & $\%$ & 65.4 & 43.1 & \\
\hline \multirow{2}{*}{ Both } & $\mathrm{n}$ & 28 & 21 & \\
\hline & $\%$ & 14.9 & 32.3 & \\
\hline \multicolumn{5}{|c|}{ In your child, over what degree do you consider as fever? } \\
\hline \multirow{2}{*}{ Do not know } & $n$ & 50 & 7 & \multirow{6}{*}{0.023} \\
\hline & $\%$ & 26.6 & 10.8 & \\
\hline \multirow{2}{*}{ Under $38^{\circ} \mathrm{C}$} & $\mathrm{n}$ & 75 & 35 & \\
\hline & $\%$ & 39.9 & 53.8 & \\
\hline \multirow{2}{*}{$38^{\circ} \mathrm{C}$ and over } & $n$ & 63 & 23 & \\
\hline & $\%$ & 33.5 & 35.4 & \\
\hline \multicolumn{5}{|c|}{ At what temperature do you use antipyretic drugs? } \\
\hline \multirow{2}{*}{ I decide by touching } & $\mathrm{n}$ & 42 & 6 & \multirow{6}{*}{0.014} \\
\hline & $\%$ & 22.3 & 9.2 & \\
\hline \multirow{2}{*}{ Under $38^{\circ} \mathrm{C}$} & $\mathrm{n}$ & 58 & 16 & \\
\hline & $\%$ & 30.9 & 24.6 & \\
\hline \multirow{2}{*}{$38^{\circ} \mathrm{C}$ and over } & $\mathrm{n}$ & 88 & 43 & \\
\hline & $\%$ & 46.8 & 66.2 & \\
\hline
\end{tabular}

a study by Hiller et al, it has been found that parents alternately use paracetamol and ibuprofen to bring fever down (24). In a study from Turkey, the rate of using antipyretics alternately by parents has been found as $44 \%$ and most parents have stated that they gave the drugs as such with the recommendation of the pediatricians (21). Similar to other studies, our study found that approximately half of the parents used different antipyretics alternately.

In a study from Taiwan, $89.5 \%$ of the parents have been found to give antipyretic drugs prior to the clinic visit (6). Wallenstein et al. indicate that $89 \%$ of the caregivers give antipyretic drug to a febrile child who looks comfortable (26). Çınar et al. have found that $58.5 \%$ of the parents sleep in the same room with the child when he/she has fever and 33.2\% wake the child up to give the antipyretic drug (27). Similarly, our study found that a majority of the parents (73.5\%) gave antipyretics before visiting the physician and woke the child up at night to give the antipyretic drug (74\%).

Parents frequently practice physical methods to bring the fever down including removing the clothes, giving a bath, applying cold and wet towels $(10,28,29)$. Forty-seven percent of the Sudanese mothers have been found to apply wet towels to bring the fever down, and most have been reported to use the water in the refrigerator or earthenware jar (30). In some studies, it has been determined that parents also use liquids like vinegar, cologne or alcohol to bring the fever down $(14,25,31,32)$. However, physical practices like cold baths and alcohol application are not recommended due to their possibility of causing side effects (33). Similarly in our study, it was found that parents removed clothes, gave warm baths, and applied the child with water-soaked wet towel, and despite rarely, the parents also wiped the child with cologne/alcohol and vinegar.

This study has some limitations, First, since this was a single-center study, the results cannot be generalized. Second, data obtained in the study rely on the expressions of the parents.

To conclude, it was found in the study that parents' knowledge on fever was insufficient, they were concerned over fever, checked the fever frequently, woke the child up at night, gave antipyretics even at low temperatures, and alternately used antipyretics. Our results show the need for parents to be informed by healthcare providers on the proper management of fever at home and prevent misguided antipyretic practices. Proper fever management at home should be provided by giving parents health education on fever in children. 
Table 4. Parents' practices on fever management

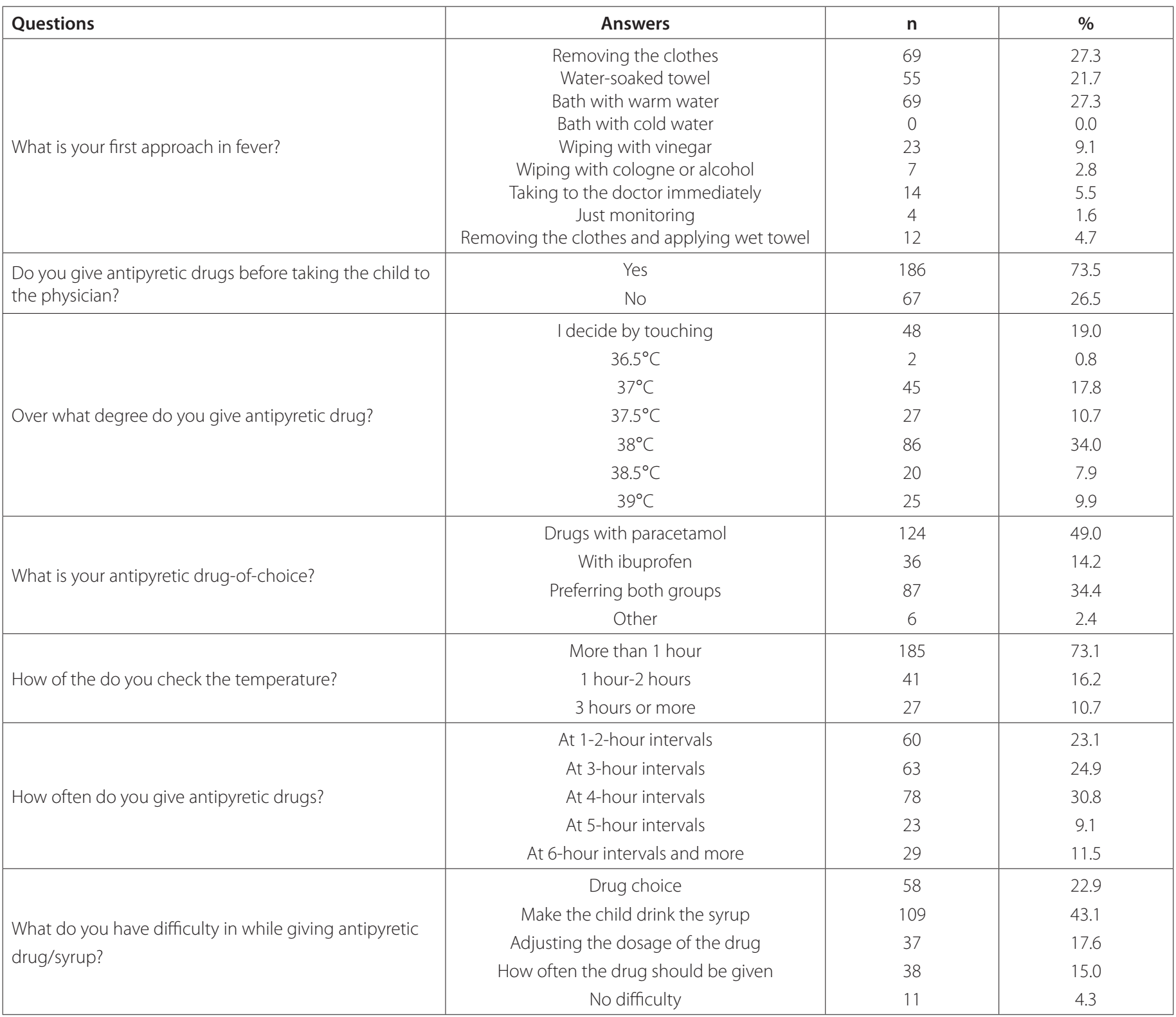

Ethics Committe Approval: This study approval obtained from Gaziantep University Faculty of Medicine Ethical Committee (Decision no: 2019/424).

Informed Consent: Patient consent was obtained.

Peer-review: Externally peer-reviewed.

Author Contributions: Concept - HTA; Design - HTA; Supervision - HTA; Resource - HTA; Data Collection and/or Processing - HTA; Analysis and/or Interpretation - HTA; Literature Search - HTA; Writing - HTA; Critical Review - HTA.

Conflict of Interest: All authors declare that they have no conflicts of interest or funding to disclose.
Financial Disclosure: The authors declared that this study has received no financial support.

\section{References}

1. Peetoom KK, Smits JJ, Ploum LJ, Verbakel JY, Dinant GJ, Cals JW. Does well-child care education improve consultations and medication management for childhood fever and common infections? A systematic review. Arch Dis Child 2017;102(3):261-7. [CrossRef]

2. Hague $R$. Managing the child with a fever. Practitioner 2015;259(1784):17-21. [CrossRef]

3. Green $R$, Jeena P, Kotze $S$, Lewis $H$, Webb D, Wells M. Management of acute fever in children: guideline for community healthcare providers and pharmacists. S Africa Med J 2013;103(12):948-4. [CrossRef] 
4. Chapron A, Brochard M, Rousseau C, Rousseau AC, Brujean M, Fiquet $L$, et al. Parental reassurance concerning a feverish child: determinant factors in rural general practice. BMC Fam Pract 2018;19(1):7. [CrossRef]

5. Section on Clinical Pharmacology and Therapeutics; Committee on Drugs, Sullivan JE, Farrar HC. Fever and antipyretic use in children. Pediatrics 2011;127(3):580-7. [CrossRef]

6. Chang LC, Liu CC, Huang MC. Parental knowledge, concerns, and management of childhood fever in Taiwan. J Nurs Res 2013;21(4):252-60. [CrossRef]

7. Zyoud SH, Al-Jabi SW, Sweileh WM, Nabulsi MM, Tubaila MF, Awang R, et al. Beliefs and practices regarding childhood fever among parents: $A$ cross-sectional study from Palestine. BMC Pediatr 2013;13:66. [CrossRef]

8. Schmitt BD. Fever phobia: misconceptions of parents about fever. Am J Dis Child 1980;134:176-81. [CrossRef]

9. Crocetti M, Moghbeli N, Serwint J. Fever phobia revisited: have parental misconceptions about fever changed in 20 years? Pediatrics 2001;107:1241-6. [CrossRef]

10. Yavuz E, Yayla E, Cebeci SE, Kırımlı E, Gümüştakım RS, Cakır L, et al. Parental beliefs and practices regarding childhood fever in Turkish primary care. Niger J Clin Pract 2017;20(1): 93-8. [CrossRef]

11. Kılıç R, Kendir ÖT, Gökay SS, Çelik T, Özkaya AK, Yılmaz HL. Çocuklarda ateş ile ilgili ebeveynlerin tutum ve davranışları. J Pediatr Emerg Intensive Care Med 2016;3:76-85. [CrossRef]

12. Chiappini E, Bortone B, Galli L, de Martino M. Guidelines for the symptomatic management of fever in children: systematic review of the literature and quality appraisal with AGREE II. BMJ Open 2017;7(7): e015404. [CrossRef]

13. Hussain SM, Al-Wutayd O, Aldosary AH, Al-Nafeesah A, AlE'ed A, Alyahya MS, et al. Knowledge, attitude, and practice in management of childhood fever among saudi parents. Glob Pediatr Health 2020;7:2333794X20931613. [CrossRef]

14. Betz MG, Grunfeld AF. 'Fever phobia' in the emergency department: a survey of children's caregivers. Eur J Emerg Med 2006;13(3):129-33. [CrossRef]

15. Katz-Sidlow RJ, Rowberry JP, Ho M. Fever determination in young infant: Prevalence and accuracy of parental palpation. Pediatr Emerg Care 2009;25:12-4. [CrossRef]

16. Erkek N, Senel S, Sahin M, Ozgur O, Karacan C. Parents' perspectives to childhood fever: comparison of culturally diverse populations. J Paediatr Child Health 2010;46(10):583-7. [CrossRef]

17. Barbi E, Marzuillo P, Neri E, Naviglio S, Krauss BS. Fever in children: pearls and pitfalls. Children (Basel) 2017;4(9):81. [CrossRef]

18. Kelly M, Sahm LJ, Shiely F, O'Sullivan R, de Bont EG, Mc Gillicuddy A, et al. Parental knowledge, attitudes and beliefs on fever: a cross-sectional study in Ireland. BMJ Open 2017;7(7):e015684. [CrossRef]
19. de Bont EG, Francis NA, Dinant GJ, Cals JW. Parents' knowledge, attitudes, and practice in childhood fever: an internet-based survey. $\mathrm{Br} J$ Gen Pract 2014;64(618): e10-e16. [CrossRef]

20. Kelly M, Sahm LJ, Shiely F, O'Sullivan R, de Bont EG, Mc Gillicuddy A, et al. Parental knowledge, attitudes and beliefs on fever: a cross-sectional study in Ireland. BMJ Open 2017;7(7):e015684. [CrossRef]

21. Polat M, Kara S, Tezer H, Tapısız A, Derinöz O, Dolgun A. A current analysis of caregivers' approaches to fever and antipyretic usage. J Infect Dev Ctries 2014;8(3):365-71. [CrossRef]

22. Gunduz S, Usak E, Koksal T, Canbal M. Why Fever Phobia Is Still Common?. Iran Red Crescent Med J 2016;18(8):e23827. [CrossRef]

23. Urbane UN, Likopa Z, Gardovska D, Pavare J. Beliefs, practices and health care seeking behavior of parents regarding fever in children. Medicina 2019;55(7):398. [CrossRef]

24. Hiller MG, Caffery MS, Bégué RE. A survey about fever knowledge, attitudes, and practices among parents. Clin Pediatr 2019;58(6):677-80. [CrossRef]

25. Arica SG, Arica V, Onur H, Gülbayzar S, Dağ H, Obut Ö. Knowledge, attitude and response of mothers about fever in their children. Emerg Med J 2012;29(12):e4. [CrossRef]

26. Wallenstein MB, Schroeder AR, Hole MK, Ryan C, Fijalkowski N, Alvarez E, et al. Fever literacy and fever phobia. Clin Pediatr 2013;52(3):254-9. [CrossRef]

27. Cinar ND, Altun I, Altinkaynak S, Walsh A. Turkish parents' management of childhood fever: A cross-sectional survey using the PFMS-TR. Australas Emerg Nurs J 2014;17:3-10. [CrossRef]

28. Agrawal RP, Bhatia SS, Kaushik A, Sharma CM. Perception of fever and management practices by parents of pediatric patients. Int $J$ Res Med Sci 2017;1(4):397-400. [CrossRef]

29. AlAteeq MM, AlBader BO, Al-Howti SY, Alsharyoufi M, Abdullah $J B$. Parent's knowledge and practice in home management of fever in their children in Riyadh, Saudi Arabia. J Family Med Prim Care 2018;7(5):1012-18. [CrossRef]

30. Mukhtar HM, Elnimeiri MK. Physical methods used by Sudanese mothers in rural settings to manage a child with fever. Sudan J Paediatr 2014;14(1):59-64. [CrossRef]

31. Badawy NAK, Alhajraf AF, Alsamdan MF. Kuwaiti parent's knowledge of their children's fever and their patterns of use of over the counter antipyretics. AMJ 2017;10(10):848-55. [CrossRef]

32. Barutcu A, Barutcu S. Evaluation of knowledge, attitudes and practices of parents presenting to a hospital emergency department with a complaint of fever in a child. Signa Vitae 2020;16(1):123-9. [CrossRef]

33. Thompson AP, Nesari M, Hartling L, Scott SD. Parents' experiences and information needs related to childhood fever: a systematic review. $\mathrm{Pa}$ tient Educ Couns 2020;103(4):750-63. [CrossRef] 